\title{
PEMBERDAYAAN MASYARAKAT MELALUI PENINGKATAN KETERAMPILAN USAHA OLAHAN HASIL PERIKANAN
}

\section{Empowerment Of Communities Through Improving The Skills Of Processed Fish Products}

\author{
Yuniarti Koniyo ${ }^{1)}$ \\ 1,Program Studi Budidaya Perairan, Fakultas Perikanan dan Ilmu Kelautan \\ Universitas Negeri Gorontalo \\ Email: Yuniarti.Koniyo@ung.ac.id ${ }^{1)}$
}

\begin{abstract}
ABSTRAK
Tujuan utama kegiatan pengabdian ini adalah1) Mengembangkan kepedulian civitas akademika terhadap kondisi ekonomi masyarakat melalui penerapan ilmu pengetahuan dan teknologi dalam olahan hasil perikanan.2) Memberikan pelatihan berupa keilmuan praktis dan bantuan teknologi yang sangat dibutuhkan masyarakat.3) Mengembangkan semangat wirausaha, selalu berpikir kreatif dalam memecahkan masalah dan persoalan masyarakat dengan mengembangkan pola kemandirian usaha perikanan melalui penerapan ilmu pengetahuan dan teknologi dalam olahan berbagai hasil perikanan. Metode yang diterapkan dalam kerangka pemberdayaan kelompok masyarakat pada program pengabdian adalah antara lain: kegiatan observasi, wawancara, focus group discussion (FGD), penyuluhan, pelatihan,pendampingan, pembimbingan, monitoring dan evaluasi. Hasil evaluasi kegiatan pengabdian menunjukkan bahwa capaian program utama dan program tambahan pengabdian di Desa Modelomo Kecamatan Kabila Bone Kabupaten Bone Bolango dapat dilaksanakan dan terealisasi 100\% sesuai dengan rencana dan kesepakatan semua pihak termasuk aparat desa, masyarakat dan tim pengabdi. Hasil evaluasi tingkat pemahaman tentang penguasaan materi pengabdian diperoleh hasil bahwa masyarakat sekitar $85 \%$ terjadi peningkatan wawasan, pengetahuan dan pemahaman tentang penerapan ilmu dan teknologi dalam pembuatan olahan hasil perikanan berupa krupuk cakalang dan sosis ikan.
\end{abstract}

Kata Kunci : Pemberdayaan, masyarakat, olahan hasil perikanan

\begin{abstract}
The main objectives of this dedication activity are 1) Improving students' caring and empathy attitudes towards the economic conditions of the society through the application of science and technology (IPTEKS) in processed fishery products and providing effective scientific services and real technology assistance that is needed by the community. 2) Developing the spirit of entrepreneurship by thinking creatively in solving problems and problems of social groups by generating patterns of independence of fisheries businesses through the application of science and technology (IPTEKS) in processed fishery products. The methods applied in the framework of society group empowerment in the service program, i.e., observation activities, interviews, focus group discussions (FGD), counseling, training, mentoring, guidance, monitoring, and evaluation. The results of social community service give the main program of achievements and additional service programs in Modelomo Village, Kabila Bone District, Bone Bolango District can be implemented and realized by following the plans and agreements of all parties, including village officials, the society and the service team. The results of the evaluation level of real understanding obtained that the community around $85 \%$ there was an increase in insight and knowledge of the application of science and technology in the manufacture of processed fishery products in the form of cakalang crackers and fish sausages.
\end{abstract}

Keywords: Empowerment, society, processed fishery products 


\section{PENDAHULUAN}

Usaha pengolahan ikan di Indonesia sejak tahun - tahun terakhir memiliki peluang yang sangat baik. Usaha pengolahan ikan tersebut terutama didorong oleh kebijakan pemerintah yang memberikan prioritas sangat tinggi. Hal ini berkaitan dengan masih rendahnya masyarakat Indonesia mengkonsumsi ikan.

Usaha pengolahan ikan memang sangat strategis untuk menggerakkan aktifitas usaha sub sektor Perikanan. Kegiatan usaha tersebut memungkinkan ikan yang dihasilkan petani ikan dapat disajikan secara lezat dan menarik selera. Pengolahan ikan sendiri dibagi menjadi dua kelompok, yakni pengolahan tradisional dan pengolahan modern. Kriteria pengelompokkan tersebut didasarkan pada tingkat teknologi yang digunakan, selain tingkat investasi yang ditanamkan.

Proses pengolahan dan pengawetan ikan merupakan salah satu bagian penting dari mata rantai industri perikanan. Tanpa adanya kedua proses tersebut, peningkatan produksi ikan yang telah dicapai selama ini akan sia - sia, karena tidak semua produk perikanan dapat dimanfaatkan oleh konsumen dalam keadaan baik. Pengolahan dan pengawetan bertujuan mempertahankan mutu dan kesegaran ikan selama mungkin dengan cara menghambat atau menghentikan sama sekali penyebab kemunduran mutu (pembusukan) maupun penyebab kerusakan ikan (misalnya aktivitas enzim, mikroorganisme, atau oksidasi oksigen), agar ikan tetap baik sampai ke tangan konsumen.

Tujuan utama proses pengolahan dan pengawetan ikan adalah :

1. Mencegah proses pembusukan pada ikan, terutama pada saat produksi melimpah

2. Meningkatkan jangkauan pemasaran ikan

3. Melaksanakan diversifikasi pengolahan produk - produk perikanan

4. Meningkatkan pendapatan nelayan atau petani ikan, sehingga mereka terangsang untuk melipatgandakan produksi.

Ikan hasil pengolahan dan pengawetan umumnya sangat disukai oleh masyarakat karena produk akhirnya mempunyai ciri - ciri khusus yakni perubahan sifat, sifat daging seperti bau (odour), rasa (flavour), bentuk (appearance) dan tekstur (Afrianto\&Liviawaty, 1989).

Masalah utama yang di hadapi oleh kelompok masyarakat pesisir adalah keterbatasan pengetahuan dan teknologi. Pengolahan dan pengawetan ikan dari hasil produksi perikanan masih kurang maksimal dalam peningkatan pendapatan masyarakat. Dalam upaya peningkatan produksi perikanan pada sebagian masyarakat pesisir untuk pengetahuan dan penerapan teknologi masih terbatas.

Tujuan kegiatan pengabdian ini adalah mengembangkan kepedulian terhadap kondisi ekonomi masyarakat melalui penerapan ilmu pengetahuan dan teknologi dengan cara pengolahan berbagai hasil perikanan, memberikan pelatihan berupa keilmuan praktis dan bantuan teknologi yang sangat dibutuhkan masyarakat dan mengembangkan semangat kewirausahaan, selalu berpikir kreatif dalam memecahkan masalah dan persoalan masyarakat dengan mengembangkan pola kemandirian usaha perikanan melalui penerapan ilmu pengetahuan dan teknologi dalam olahan berbagai hasil perikanan.

\section{METODE PELAKSANAAN}

Kegiatan pengabdian dilakukan dengan metode partisipatif akktif semua masyarakat dan praktek langsung di lapanagan sebagai suatu metode pembelajaran pemberdayaan masyarakat. Kegiatan ini melibatkan narasumber termasuk tokoh masyarakat sebagai penggerak mitra masyarakat di desa. Metode ini dapat memberikan nilai-nilai kemandirian dalam berfikir dan membangun kerja sama tim atau kelompok.

Langkah-langkah operasional yang diperlukan untuk mengatasi Permasalahan adalah proses pendampingan penyelesaian masalah tentang pemilihan bahan baku produk olahan, menyusun formulasi bahan-bahan olahan hasil perikanan, teknologi pengolahan, melakukan diversifikasi pengolahan hasil perikanan.

\section{HASIL DAN PEMBAHASAN}

Pengabdian pada masyarakat di Desa Modelomo Kecamatan Kabila Bone Kabupaten Bone Bolango dapat dilaksanakan dan 
terealisasi $100 \%$ sesuai dengan rencana dan kesepakatan semua pihak termasuk aparat desa, masyarakat dan pembimbing DPL. Hasil evaluasi tingkat pemahaman tentang penguasaan materi pengabdian diperoleh hasil bahwa masyarakat sekitar $85 \%$ terjadi peningkatan wawasan, pengetahuan dan pemahaman tentang penerapan ilmu dan teknologi dalam pembuatan olahan hasil perikanan berupa krupuk cakalang dan sosis ikan.

Program yang telah dilakukan oleh mahasiswa selama kegiatan pengabdianadalah memberikan pendampingan pemberdayaan partisipasi aktif kelompok masyarakat dengan transfer ilmu dan teknologi, penerapan ilmu dan teknologi melalui :

a. Pemilihan bahan baku produk olahan

b. Teknik penyusunan formulasi bahan-bahan olahan hasil perikanan,

c. Teknologi pengolahan

d. Diversifi kasi pengolahan hasil perikanan (berbagai produk krupuk cakalang dan sosis ikan)

e. Pengemasan.

f. Pengujian organoleptik berbagai hasil olahan

g. Manajemen pemasaran

Sifat mandiri secara finansial sangat penting untuk ditanamkan pada masyarakat desa dalam hal ini Desa Modelomo, khususnya masyarakat kurang mampu karena sifat ini adalah salah satu cara untuk memberantas kemiskinan di pedesaan. Kemudian jalan yang dapat ditempuh untuk memberantas kemiskinan itu sendiri sangatlah banyak. Salah satunya yakni dengan membekali masyarakat desa dengan keterampilan yang dapat diterapkan dengan mudah oleh masyarakat desa. Konsep pengabdian disini dapat digunakan untuk mengembangkan perekonomian masyarakat desa agar bisa lebih mandiri secara finansial yaitu dengan memanfaatkan sektor potensial yang ada di desa dan menjadikannya berharga sebagai produk unggulan yang bernilai dan dapat diproduksi secara berkelanjutan sehingga kebermanfaatan nya dapat dirasakan secara berkelanjutan. Desa modelomo yang memiliki potensi ikan cakalang cukup besar dapat dimanfaatkan potensi tersebut untuk mengembangkan perekonomian masyarakat dengan membuat sebuah produk olahan ikan yang bernilai dan potensial untuk di kembangkan.

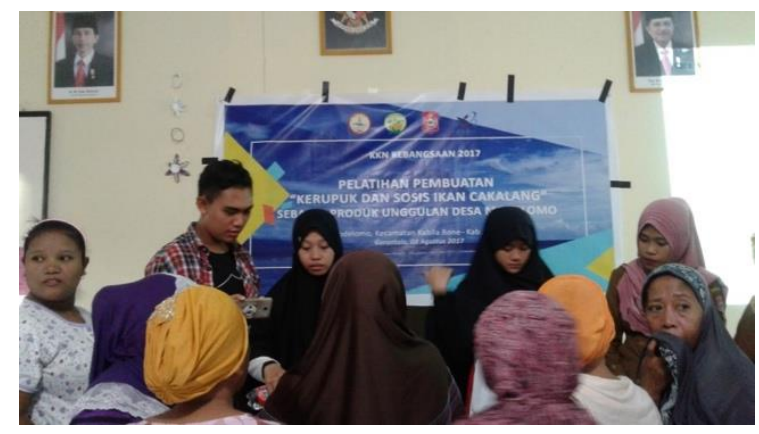

Gambar 1.

Untuk menjalankan suatu usaha bersama diperlukan kerjasama yang baik antar anggota. Disini komitmen membangun usaha bersama sangat perlu untuk dibangun karena usaha umumnya bermula dari kecil hingga menjadi besar. Maka dari itu saran yang dapat diberikan untuk masyarakat anggota Kelompok Usaha Bersama (KUB) untuk kedepannya masyarakat bisa lebih memanfaatkan teknologi informasi yang ada (smartphone) untuk mengembangkan produk unggulan desa yakni kerupuk ikan. Contohnya dalam hal kemasan, disini masyarakat bisa lebih berpikir kreatif untuk mengemas bagaimana kemasan yang bagus dadapat menarik konsumen sehingga produk selalu bisa kompetitif berada di pasaran.

Berdasarkan kegiatan Pengabdian, masyarakat dapat meningkatkan wawasan, ketrampilan dalam penguasaan teknologi tepat guna, peningkatan produksi, peningkatan pendapatan dan manajemen usaha. Bagi Lembaga Pengabdian Pada Masyarakat UNG pelaksanaan kegiatan ini dapat menjaga kemitraan dan kemanunggalan antara UNG dengan masyarakat. Bagi dosen pelaksana kegiatan ini merupakan salah wadah untuk menyebarluaskan hasil penelitian ke masyarakat sebagai perwujudan dari dharma ketiga dari Tri Dharma Perguruan Tinggi, yatu pengabdian kepada masyarakat.

Untuk mengukur tingkat keberhasilan program pengabdian ini di lakukan evaluasi terhadap keseluruhan program. Dari hasil evaluasi tentang tingkat pemahaman menunjukkan bahwa kegiatan ini memenuhi kriteria keberhasilan yang telah ditetapkan. Hal ini dapat dilihat dari kriteria keberhasilan, yaitu: $85 \%$ terjadi peningkatan wawasan, 
pengetahuan dan pemahaman tentang : pemilihan bahan baku produk olahan, teknik penyusunan formulasi bahan-bahan olahan hasil perikanan, teknologi pengolahan, diversifikasi pengolahan hasil perikanan (berbagai produk krupuk cakalang dan sosis ikan), pengemasan, pengujian organoleptik berbagai hasil olahan dan menejemen pemasaran.

Kerupuk dan sosis ikan merupakan produk hasil perikanan yang terbuat dari campuran daging ikan dan bumbubumbu/bahan pembantu lainnya yang melewati proses pengadonan, percetakan, perebusan/pengukusan, pengirisan dan untuk kkrupuk dilakukan pengiringan. Pembuatan kerupuk ikan dan sosis ikan bertujuan membuat diversifikasi olahan hasil perikanan agar produk dapat bertahan lama (awet) sehingga dapat dikonsumsi dengan aman.

Program pelatihan pembuatan kerupuk ikan ini digagas oleh mahasiswa Pengabdian Desa Modelomo untuk membekali masyarakat khususnya ibu-ibu rumah tangga yang menganggur agar bisa lebih produktif dengan memanfaatkan sektor potensial nya yakni ikan cakalang menjadi sebuah produk unggulan desa. Produk yang coba dikembangkan dalam pelatihan ini adalah keupuk ikan cakalang. Ada beberapa alasan dari pemilihan produk kerupuk ikan cakalang ini, yang pertama adalah mudah. Untuk membuat kerupuk ikan cakalang ini sangatlah mudah, tanpa menggunakan teknologi yang canggih. Alat dan bahan yang digunakan pun mudah didapat di Desa Modelomo sendiri, sehingga harapannya tidak memberatkan masyarakatnya. Kedua, potensi unggulan Desa Modelomo sendiri berbeda dengan desa desa uang ada di kecamatan Kabila Bone. Jika desa lain terkenal dengan pantai wisata nya, maka di Desa Modelomo tidak ada. Karena perairan di Desa Modelomo sedikit menjauh dari bibir pantai sudah masuk pada perairan dalam. Maka dari itu potensi Desa Modelomo paling menonjol adalah hasil laut (ikan cakalang) bukan daerah wisata. Yang ketiga, dinamika dari masyarakat Desa Modelomo kebanyakan dari mereka tidak mau "ribet" untuk itulah pembuatan olahan kerupuk ikan cakalang yang sederhana ini harapannya dapat diterima dengan baik oleh masyarakat dan nantinya dapat diterapkan dan dijalankan dengan baik oleh masyarakat. Kondisi masyarakat Desa Modelomo mayoritas adalah keluarga yang kurang mampu sehingga sangat tidak mungkin jika mau mengembangkan olahan ikan dengan teknologi canggih yang ada mengingat masyarakatnya sendiri dalam memenuhi hidupnya tergantung pada hasil laut. Dan yang terakhir, banyaknya tingkat pengangguran di Desa Modelomo.

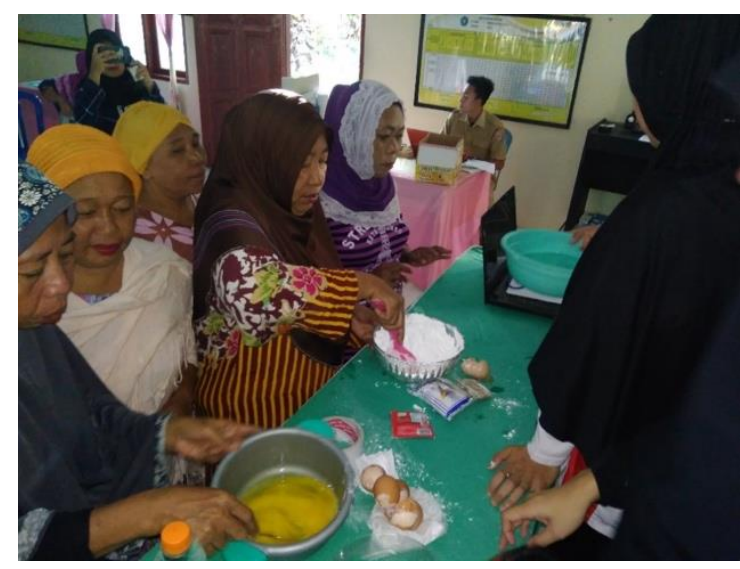

Gambar 2.

$\begin{array}{cc}\text { Harapan } & \text { kedepannya adalah, } \\ \text { masyarakat Desa } & \text { Modelomo dapat }\end{array}$ mengembangkan sektor potensial desa dengan menjadikannya sebagai produk unggulan melalui pembuatan kerupuk ikan yang sasaran dari pemasaran olahan ini ada di pantai-pantai wisata hingga nanti dapat di ekspor hingga keluar kabupaten Bone Bolango dan tersebar di setiap daerah wisata di Gorontalo.

\section{KESIMPULAN DAN SARAN}

Pengabdian pada masyarakat di Desa Modelomo Kecamatan Kabila Bone Kabupaten Bone Bolango dapat dilaksanakan dan terealisasi $100 \%$ sesuai dengan rencana dan kesepakatan semua pihak termasuk aparat desa, masyarakat dan pembimbing DPL. Hasil evaluasi tingkat pemahaman tentang penguasaan materi pengabdian diperoleh hasil bahwa masyarakat sekitar $85 \%$ terjadi peningkatan wawasan, pengetahuan dan pemahaman tentang penerapan ilmu dan teknologi dalam pembuatan olahan hasil perikanan berupa krupuk cakalang dan sosis ikan. 


\section{DAFTAR PUSTAKA}

Adawyah, R. 2011. Pengolahan dan Pengawetan Ikan. Penerbit Bumi Aksara. Jakarta. $160 \mathrm{hlm}$.

Dinas Perikanan dan Kelautan Provinsi Gorontalo,2015. Provinsi Gorontalo Dalam Angka 2015. Bappeda dan BPS Provinsi Gorontalo.

Dinas Perikanan dan Kelautan Kabupaten Gorontalo Utara ,2015. Profil Perikanan dan Kelautan Gorontalo utara.

Direktorat Jenderal Penguatan Daya Saing Produk Kelautan dan Perikanan, 2014. Pengembangan Produk Hasil Perikanan. Kementerian Kelautan dan Perikanan

Direktorat Jenderal Penguatan Daya Saing Produk Kelautan dan Perikanan, 2015. Pengembangan Produk Hasil Perikanan. Kementerian Kelautan dan Perikanan

Nurjanah, Abdullah A, Tarman K. 2011. Pengetahuan dan Karakteristik Bahan Baku Hasil Perairan. Bogor (ID): IPB Press. 